\title{
FAKTOR-FAKTOR YANG MEMPENGARUHI PERSEPSI NAZHIR TERHADAP WAKAF UANG
}

\author{
Rahmat Dahlan ${ }^{1}$
}

\begin{abstract}
Factors That Influence Nazhir Perception on Cash Waqf. The purpose of this study is to analyze what factors are influencing cash waqf perceptions of nazhir. The sampling method that used in this research is nonprobability sampling with adjusted sampling technique. The method was used to analyze the data are descriptive analysisi and logistic regression. The result of this study showed that perception nazhir influenced by the media access information and understanding of waqf regulation. Nazhir that agree with cash waqf and understand with waqf regulation is about 0,94 times if we compare with the nazhir that not understand with waqf requlation. The educational background will be influence to the mindset of nazhir perception and understanding.
\end{abstract}

Keywords : Cash Waqf, Logistic Regression, Nazhir, Perception

\begin{abstract}
Abstrak: Faktor-faktor Yang Memengarubi Persepsi Nazhir Terhadap Wakaf Uang. Tujuan dari penelitian ini ialah untuk menganalisis faktorfaktor yang mempengaruhi persepsi para nazhir mengenai wakaf uang. Dalam pengambilan sampel digunakan teknik non probability sampling dengan teknik adjusted sampling. Metode yang dipergunakan dalam penelitian ini ialah analisis deskriptif dan regresi logistik. Hasil yang didapat dari penelitian ini menunjukkan bahwa persepsi nazir dipengaruhi oleh akses terhadap media informasi dan pemahaman atas aturan mengenai wakaf. Nazhir yang menyatakan setuju terhadap wakaf uang dan paham terhadap regulasi wakaf sebanyak 0,94 kali dibandingkan dengan nazhir yang tidak paham regulasi wakaf. Latar belakang pendidikan akan berpengaruh terhadap terbentuknya persepsi atau pemahaman nazhir.
\end{abstract}

Kata Kunci: Wakaf Uang, Regresi Logistik, Nazhir, Persepsi

${ }^{1}$ Diterima: 18 April 2014, direvisi: 25 Mei 2014, disetujui: 3 Juni 2014

Universitas Prof. Dr. Hamka, Jl. Limau II, Kebayoran Baru, Jakarta Selatan

Email: Rhahmat@yahoo.com 


\section{PENDAHULUAN}

Wakaf adalah salah satu lembaga ekonomi Islam yang sangat erat kaitannya dengan masalah sosial dan ekonomi nazhir. Wakaf merupakan bentuk ibadah yang dilakukan dengan memisahkan harta milik pribadi untuk dijadikan harta milik umum. Berdasarkan maknanya yang umum, wakaf memberikan harta atau pokok benda yang produktif terlepas dari campur tangan pribadi, menyalurkan hasil dan manfaatnya secara khusus sesuai dengan tujuan wakaf, baik untuk kepentingan perorangan, nazhir, agama atau umum. (Qahaf: 2007)

Indonesia menyimpan potensi wakaf yang besar. Tapi, potensi itu belum dikelola dan dimanfaatkan secara optimal. Menurut data Departemen Agama hingga Maret 2008, aset wakaf yang berupa tanah berjumlah 363.272 lokasi dengan luas mencapai $2.701 .145 .561,08 \mathrm{~m}^{2}$. Tanah wakaf tersebut sebagian besar baru dimanfaatkan untuk pendirian masjid, panti asuhan, sarana pendidikan dan kuburan dan hanya sebagian kecil yang dikelola secara produktif (Depag: 2008)

Hal ini diperkuat dengan hasil penelitian Pusat Bahasa dan Budaya (PBB) UIN Syarif Hidayatullah Jakarta (CSRC UIN: 2006) menunjukkan, bahwa harta wakaf lebih banyak bersifat diam (77\%) daripada yang menghasilkan atau produktif (23\%). Temuan lain menunjukkan, pemanfaatan terbesar harta wakaf adalah masjid (79\%) daripada peruntukkan lainnya, dan lebih banyak berada di wilayah pedesaan (59\%) daripada perkotaan (41\%). Artinya bahwa tanah wakaf yang cukup luas itu belum memberikan manfaat produktif, melainkan sebagian besar masih dipergunakan untuk keperluan konsumtif. (Nasution\& Hasanah: 2005) Tanah wakaf seluas 270.114,56 hektar akan memberikan manfaat yang lebih besar apabila dipergunakan untuk kepentingan produktif, seperti rumah sakit, pusat bisnis, pertanian, perkebunan dan lain-lain.

Potensi wakaf diatas belum termasuk potensi wakaf benda tak bergerak misalnya wakaf uang. Wakaf uang ini merupakan implementasi produk baru dalam sejarah perekonomian Islam yang dipelopori oleh Muhammad Abdul Mannan, di Bangladesh. Wakaf uang mendapat perhatian serius karena memiliki akar panjang dalam sejarah Islam. Sebagai instrumen keuangan, wakaf uang merupakan produk baru dalam sejarah perbankan Islam. Pemanfaatan wakaf uang yang dipelopori Mannan dibedakan menjadi dua, yaitu pengadaan barang privat dan barang sosial. Karena itu wakaf uang membuka peluang yang unik bagi penciptaan investasi di bidang keagamaan, pendidikan dan pelayanan sosial. Tabungan dari warga yang berpenghasilan tinggi dapat dimanfaatkan melalui penukaran sertifikat wakaf uang. 
Menurut perhitungan Nasution(2005) tentang potensi wakaf di Indonesia dengan jumlah umat muslim dermawan diperkirakan sebesar 10 juta jiwa dengan rata-rata penghasilan perbulan Rp. 500.000 hingga Rp. 10.000.000, maka paling tidak akan terkumpul dana per bulan sekitar Tiga Triliun Rupiah pertahun dari dana wakaf, seperti perhitungan pada Tabel 1 berikut:

Tabel 1 Perhitungan Potensi Wakaf Uang

\begin{tabular}{lllll}
\hline $\begin{array}{c}\text { Tingkat } \\
\begin{array}{c}\text { Penghasilan/ } \\
\text { bulan }\end{array}\end{array}$ & $\begin{array}{c}\text { Jumlah } \\
\text { Muslim }\end{array}$ & $\begin{array}{c}\text { Tarif Wakaf/ } \\
\text { bulan }\end{array}$ & $\begin{array}{c}\text { Potensi Wakaf } \\
\text { Uang/bulan }\end{array}$ & $\begin{array}{c}\text { Potensi Wakaf } \\
\text { Uang/tahun }\end{array}$ \\
\hline $\begin{array}{l}\text { Rp500.000 } \\
\text { Rp1 Juta-Rp2 }\end{array}$ & 4 juta & Rp5000,- & Rp20 Milyar & Rp240 Milyar \\
$\begin{array}{l}\text { Juta } \\
\text { Rp2 Juta-Rp5 }\end{array}$ & 2 Juta & Rp10.000,- & Rp30 Milyar & Rp360 Milyar \\
$\begin{array}{l}\text { Juta } \\
\text { Rp5 Juta-10 Juta }\end{array}$ & 1 Juta & Rp50.000,- & Rp100 Milyar & Rp1,2 Triliun \\
Total & & & Rp100 Milyar & Rp1,2 Triliun \\
\hline
\end{tabular}

Sumber : Nasution dan Hasanah (2005)

Adapun Dana wakaf yang terkumpul ini selanjutnya dapat digulirkan dan diinvestasikan oleh nazhir ke dalam berbagai sektor usaha yang halal dan produktif, misalnya membangun sebuah kawasan perdagangan yang sarana dan prasarananya dibangun di atas lahan wakaf dan dari dana wakaf. Proyek ini ditujukan bagi kaum miskin yang memiliki bakat bisnis untuk terlibat dalam perdagangan pada kawasan yang strategis dengan biaya sewa tempat yang relatif murah. Sehingga akan mendorong penguatan pengusaha muslim pribumi dan sekaligus menggerakkan sektor riil secara lebih massif. Kemudian, keuntungannya dapat dimanfaatkan untuk pembangunan umat dan bangsa secara keseluruhan (Nasution: 2006).

Wakaf yang ada di Indonesia dikelola oleh nazhir wakaf dibagi menjadi tiga kategori: Pertama nazhir perorangan, yaitu minimal terdiri dari $r$ orang nazhir perorangan biasanya tidak memiliki kepengurusan yang jelas dan tidak memiliki kekuatan hukum seperti akta notaris; kedua, nazhir organisasi; dan ketiga, nazhir badan hukum, yaitu organisasi atau badan hukum yang bergerak dalam bidang sosial keagamaan. Nazhir perorangan pada umumnya belum mampu mengembangkan dana wakaf yang ada di bawah tanggung jawabnya. Sedangkan nazhir badan hukum baru sedikit yang mampu mengembangkan wakaf secara produktif (Nasution: 2005).

Keberadaan nazhir memegang peranan yang sangat penting bagi berkembang 
tidaknya suatu harta wakaf. Dalam literatur fikih, pengelola wakaf disebut nazhir. Istilah ini mengandung arti penjaga, manajer, administrator, kepala atau direktur. Selain itu sering juga disebut dengan mutawalli, yang berarti pengurus, yang diberi kuasa dan berkomitmen, eksekutif, manajer atau direktur.

Sebesar apapun aset wakaf yang dimiliki bila tidak ditangani oleh Sumber Daya Manusia (SDM) nazhir yang handal dan profesional, maka aset wakaf tetap diam, dan tidak bergerak ke arah produktif. Seperti yang terjadi pada aset wakaf berupa tanah. Kondisi pengelolaan tanah wakaf yang kurang produktif itu berbanding lurus dengan kualitas pengelolanya. Seharusnya dengan potensi wakaf uang yang begitu besar apabila dikelola dengan baik maka akan menghasilkan penghimpunan dana wakaf uang yang besar tapi kenyataannya terjadinya gap yang sangat lebar antara realisasi dana wakaf yang dihimpun dengan potensi wakaf uang yang ada. Penulis menduga manajemen pengelolaan wakaf uang kurang dikelola dengan baik dan kurang profesional maka output penghimpunan dana wakaf uang yang dihasilkan juga tidak maksimal.

Rendahnya pemanfaatan wakaf ini identik dengan rendahnya kemampuan nazhir. Menurut Hasanah, masih banyak Nazhir yang kurang mampu memahami tugas dan kewajiban selaku pengelola wakaf. Pengelolaan wakaf di masa mendatang harus dilakukan oleh nazhir yang profesional sehingga wakaf bisa berkembang produktif. (Hasanah: 2005)

Masih rendahnya tingkat pemahaman nazhir mengenai wakaf uang dan pemahaman Undang-undang No.41 Tahun 2004 tentang wakaf merupakan suatu realita yang tidak dapat terbantahkan. Sebagian besar nazhir masih memahami bahwa mengelola harta wakaf adalah bagaimana mengelola dan mengembangkan wakaf yang hanya berupa benda seperti bangunan atau tanah. Konsep wakaf yang masih mengacu pada fixed asset.

\section{TINJAUAN PUSTAKA}

Menurut Robbin (2001) ada banyak faktor yang mempengaruhi terbentuknya persepsi seseorang dan faktor itu yang memungkinkan terjadinya perbedaan persepsi antar individu terhadap suatu objek tertentu. Faktor-faktor tersebut dapa berada pada tida aspek, yaitu: pihak pelaku persepsi, pada target persepsi (objek persepsi) dan juga dapat dari konteks situasi persesi itu dilakukan. Faktor yang bersumber dari pihak pelaku persepsi dalam menafsirkan sebuah objek sangat dipengaruhi oleh karakteristik pribadi. Banyak faktor yang terkait dengan individu pelaku persepsi yang mempengaruhi persepsinya seseorang seperti sikap, motif, kepentingan atau minat, pengalaman masa lalu dan pengharapan. 
Objek dari persepsi tersebut menjadi faktor kedua dalam mempengaruhi persepsi seseorang. Orang yang pintar bicara di depan publik lebih mungkin untuk diperhatikan dalam suatu kelompok daripada mereka yang pendiam. Demikian juga individu yang luar biasa menarik atau luar biasa tidak menarik, gerakan, bunyi dan atribut-atribut lain dari objek persepsi membentuk cara kita memandangnya. Faktor ketiga yaitu situasi dan kondisi lingkungan sekitar. Persepsi terhadap suatu objek menjadi berbeda walau pelakunya juga sama, tetapi kondisinya berbeda.

Berdasarkan kerangka teori di atas, persepsi nazhir wakaf uang juga dipengaruhi oleh faktor-faktor yang terkait dengan tiga aspek tersebut. Diantara faktor-faktor yang akan berpengaruh pada nazhir dalam memahami wakaf uang adalah: Faktor pertama yang akan berpengaruh kepada persepsi nazhir tentang wakaf uang adalah keterlibatan dan interaksi nazhir dengan pelatihan-pelatihan wakaf. Pelatihan tersebut dapat berupa seminar, workshop, pendidikan dan pelatihan (diklat) dsb. Faktor kedua latar belakang pendidikan akan berpengaruh terhadap terbentuknya persepsi atau pemahaman nazhir, karena nazhir yang berpendidikan akan memiliki sikap terbuka terhadap informasi baru dan memandangnya secara obyektif. Pendidikan merupakan proses memberi informasi dan melatih kemampuan seseorang untuk menyeleksi dan menginterpretasikan sebuah informasi, demikian halnya dengan memahami wakaf uang orang yang berpendidikan akan lebih mudah dalam memahaminya.

Faktor ketiga yang akan berpengaruh terhadap persepsi nazhir tentang wakaf uang adalah media informasi. Bentuk media informasi bermacam-macam, antara lain dalam media massa, media elektronik dan dakwah para ulama. Media merupakan sarana komunikasi yang dikemas dalam bentuk informasi untuk terbangunnya persepsi. Oleh karena itu, persepsi terbentuk awalnya dari adanya informasi yang menstimulasi indra manusia baik berbentuk barang dan jasa, atau berbentuk data yang datang dari objek tertentu.

Faktor keempat yang akan berpengaruh kepada persepsi nazhir tentang wakaf uang adalah regulasi. Dengan adanya Undang-undang No.41 tahun 2004 tentang wakaf dan Peraturan Pemerintah Nomor 42 Tahun 2006 tentang pelaksanannya, memberikan kepastian hukum tentang bolehnya wakaf uang serta bagaimana memproduktifkan aset wakaf semaksmimal mungkin.

Dalam kitab-kitab fikih, ulama tidak mencantumkan nazhir wakaf sebagai salah satu rukun wakaf, karena wakaf merupakan ibadah tabarru' (pemberian yang bersifat sunah). Namun demikian, setelah memperhatikan tujuan wakaf yang ingin melestarikan manfaat maka keberadaan nazhir sangat dibutuhkan, bahkan menempati pada peran sentral. Terlalu banyak contoh pengelolaan harta wakaf yang dikelola oleh nazhir yang sebenarnya tidak memiliki kemampuan yang memadai, 
sehingga harta wakaf tidak berfungsi secara maksimal, bahkan tidak memberikan manfaat sama sekali kepada sasaran wakaf. Untuk itulah profesionalisme nazhir menjadi ukuran yang paling penting dalam pengelolaan wakaf jenis apapun.

Dalam rangka meningkatkan kemampuan nazhir diperlukan sistem manajemen Sumber Daya Manusia (SDM) yang handal. Sistem tersebut bertujuan untuk: Pertama, Meningkatkan dan mengembangkan pengetahuan kemampuan dan keterampilan para nazhir wakaf di semua tingkatan dalam rangka membangun kemampuan manajerial yang tangguh, profesional dan bertanggung jawab; Kedua, Membentuk sikap dan perilaku nazhir sesuai dengan posisi yang seharusnya, yaitu pemegang amanat umat Islam yang mempercayakan harta benda untuk dikelola secara baik dan pertanggungjawaban di hadapan Allah kelak; Ketiga, Menciptakan pola pikir atau pesrepsi yang sama dalam memahami dan menerapkan pola pengelolaan wakaf, baik dari segi peraturan perundang-undangan maupun teknis manajerail sehingga lebih mudah diadakan kontrol, baik di daerah maupun pusat; Keempat, Mengajak para nazhir untuk memahami tata cara pengelolaan yang lebih berorientasi pada kepentingan Syariat Islam secara lebih luas dan dalam jangka panjang. Sehingga wakaf bisa dijadikan sebagai salah satu elemen penting dalam menunjang penerapan sistem ekonomi Syariah secara terpadu.

Setelah diketahui persyaratan minmal seorang nazhir dan tujuan diperlukan upaya pembinaan agar mereka dapat menjalani tugas-tugas kenazhiran secara produktif dan berkualitas. Upaya pembinaan ini harus dalkukan berdasatkan standar pola manajemen terkini, antara lain: Pertama, pendidikan formal. Melalui sekolahsekolah umum dan kejuruan dapat dicetak calon -calon SDM kenazhiran yang siap pakai, dengan catatan sekolah itu sendiri harus dibentuk secara berkualitas dengan memberikan format kurikulum yang mantap dengan disiplin pengajaran yang tinggi, terarah menurut bidang yang dituju. Misalnya, sekolah menengah pertanian maupun tingkat perguruan tingi yang diharapkan dapat mengelola tanah-tanah wakaf berupa persawahan, perkebunan, ladang pembibitan dan lain-lain.

Kedua, pendidikan non formal. Bentuk dari pendidikan model ini adalah dengan mengadakan kursus-kursus atau pelatihan-pelatihan SDM kenazhiran baik yang terkait dengan manajerial organisasi, atau meningkatkan keterampilan dalam bidang profesi seperti administrasi, teknik pengelolaan pertanian, teknik perbankan, pengelolaan kepariwisataan, perdagangan, pemasaran dan lain sebagainya; Keempat, pendidikan informal. Berupa latihan-latihan dan kaderisasi langsung di tempattempat pengeloaan benda wakaf. Nazhir yang telah ada, ditingkatkan kemampuannya melalui latihan-latihan yang intensif dan bimbingan yang membuatnya kian maju dan mampu dalam bidang tugas dan tanggung jawabnya. Medan kerja itu sendiri menjadi "sekolah" dan taman belajar yang lebih praktis yang terkadang bobot dan 
mutunya lebih mantap dibandingkan dengan sekolah atau kursus.

Kelima, Pembinaan mental. Spirit kerja harus terus menerus dibina agar para pemegang amanah perwakafan senantiasa bergairah dalam melaksanakan pekerjaannya. Demikian juga pembinaan mental budi pekerti (akhlak) yang luhur dibina melalui berbagai kesempatan seperti ceramah-ceramah agama, outbond, simulasi pengembangan diri dan organisasi untuk menjaga dan meningkatkan ketahanan mental supaya SDM kenazhiran bisa mengemban amanat untuk kesejahteraan nazhir banyak.

\section{METODE}

Data yang digunakan yaitu data primer dan sekunder. Data primer diperoleh melalui penyebaran kuesioner. Sementara data sekunder meliputi berbagai literatur yang berkaitan dengan topik penelitian. Dalam pengambilan sampel dalam penelitian, penulis akan menggunakan teknik non probability sampling dengan teknik adjusted sampling.

Penelitian ini merupakan jenis penelitian deskriptif-korelasional (kausal) dengan melihat faktor-faktor yang ada pada variabel bebas guna melihat adakah hubungan dan seberapa besar pengaruh tiap-tiap variabel bebas terhadap variabel terikatnya. Metode yang digunakan untuk menganalisis data adalah analisis deskriptif dan regresi logistik.

Analisis deskriptif digunakan untuk menjelaskan hasil penelitian yang diperoleh dan kaitannya dengan teori-teori persepsi yang ada. Adapun analisis regresi logistik dilakukan untuk mengetahui pemahaman nazhir akan wakaf uang dan faktor yang mempengaruhi pemahaman tersebut.

Target dari analisis regresi logit adalah untuk mengetahui seberapa besar pengaruh variabel-variabel bebas terhadap variabel terikat yang dengan bentuk persamaannya :

$\begin{aligned} \ln \left(\begin{array}{c}\mathrm{p} \\ 1-\mathrm{p}\end{array}\right)= & \beta_{0}+\mathrm{Latih}_{1}+\mathrm{Latih}_{2}+\operatorname{Didik}_{1}+\mathrm{Didik}_{2}+\operatorname{Sos}_{1}+\operatorname{sos}_{2} \\ & +\operatorname{Reg}_{1}+\operatorname{Reg}_{2}+\epsilon_{1}\end{aligned}$

dimana:

Latih : Pelatihan yang diikuti

Didik : tingkat Pendidikan yang ditamatkan

Sos : Media informasi

Reg : Regulasi 


\section{PEMBAHASAN}

Sikap dan respon nazhir terhadap wakaf uang sangat dipengaruhi oleh pemahaman nazhir itu sendiri terhadap wakaf uang tersebut. Persepsi merupakan tanggapan, pendapat yang di dalamnya terkandung unsur penilaian terhadap objek dan gejala berdasarkan pengalaman dan wawasan yang dimilikinya. Pengalaman dan wawasan itu sendiri dipengaruhi oleh situasi nazhir, isu-isu sosial, kelompok sosial dan hal-hal lain yang dapat menjadi objek sikap.

Pandangan nazhir terhadap wakaf uang dapat terbentuk jika nazhir memiliki pengalaman dan wawasan mengenai wakaf. Tidak mungkin nazhir memberikan pandangan atau persepsinya terhadap wakaf uang jika nazhir tersebut tidak memahami atau mengetahui hal yang berkaitan dengan wakaf.

Hasil olahan data kuesioner tentang responden yang setuju dan tidak setuju tentang wakaf uang ditampilkan pada Tabel Variabel Persepsi Wakaf Uang sampel data yang digunakan mempunyai komposisi untuk nazhir yang setuju wakaf uang sebanyak $81,7 \%$, kemudian untuk nazhir yang tidak setuju wakaf uang sebanyak $18,3 \%$. Secara umum penelitian ini menunjukkan bahwa mayoritas nazhir setuju wakaf uang.

Latar belakang pendidikan akan berpengaruh terhadap terbentuknya persepsi atau pemahaman nazhir, karena nazhir yang berpendidikan akan memiliki sikap terbuka terhadap informasi baru dan memandangnya secara obyektif. Pendidikan merupakan proses memberi informasi dan melatih kemampuan seseorang untuk menyeleksi dan menginterpretasikan sebuah informasi, demikian halnya dengan memahami wakaf uang orang yang berpendidikan akan lebih mudah dalam memahaminya.

Hasil pengolahan data penelitian, variabel latar belakang pendidikan berpengaruh cukup besar terhadap peersetujuan terhadap wakaf uang. Data bahwa semakin tinggi pendidikan seseorang, maka akan semakin setuju terhadap wakaf uang. Pada sebaran data yang dilakukan, tingkat pendidikan yang ditamatkan oleh nazhir yang menjadi responden penelitian ini, bahwa pendidikan tertinggi adalah S3 dan yang terendah ditamatkan adalah SLTP. Apabila ditinjau dari komposisi tingkat pendidikan terhadap persetujuan tentang wakaf uang adalah sebagai berikut: Untuk pendidikan tinggi $100 \%$ responden yang setuju, kemudian untuk pendidikan menengah $86 \%$ responden yang setuju dan $14 \%$ responden yang tidak setuju akan wakaf uang. Untuk pendidikan rendah $73 \%$ responden yang setuju dan yang tidak setuju $27 \%$ responden.

Berdasarkan sebaran data yang diperoleh terlihat bahwa nazhir yang tidak pernah mengakses media informasi tentang wakaf uang sebanyak $18 \%$, yang 
kadang-kadang mengakses media informasi wakaf uang sebesar $75 \%$ serta yang sering mengakses media informasi wakaf uang $7 \%$.

Dengan adanya Undang-undang No.41 tahun 2004 tentang wakaf dan Peraturan Pemerintah Nomor 42 Tahun 2006 tentang pelaksanannya, memberikan kepastian hukum tentang bolehnya wakaf uang serta bagaimana memproduktifkan aset wakaf semaksmimal mungkin. Sebanyak 50\% responden adalah kelompok yang paham akan regulasi wakaf uang, yang kurang paham sebesar $7 \%$ responden dan yang tidak paham sebesar 35\% responden.

Regresi logistik digunakan untuk menguji probabilitas terjadinya variabel terikat dapat diprediksi dengan variabel bebasnya. Variabel terikat menggunakan nilai 0 dan 1, dimana bernilai 0 apabila responden tidak setuju wakaf uang dan bernilai 1 bila responden setuju wakaf uang. Tabel selanjutnya menginformasikan bahwa variabel bebas yang dimasukkan pada saat pengolahan data, yaitu variabel keterlibatan dalam pelatihan wakaf, tingkat pendidikan, media informasi dan regulasi. Hasilnya pada output terlihat bahwa kategori yang dibuat telah diubah sesuai dengan definisi yang diinginkan.

Variabel pendidikan yang menjadi referensi adalah kelompok pendidikan tinggi. Variabel kategori keterlibatan dalam pelatihan wakaf yang menjadi referensi adalah kelompok yang terlibat aktif dalam pelatihan wakaf. Variabel media informasi yang menjadi referensi adalah kelompok yang sering mengakses media informasi wakaf uang. Variabel kategori regulasi yang menjadi refensi adalah kelompok yang paham akan regulasi wakaf uang.

Variabel-variabel yang ditampilkan pada tabel tersebut adalah semua variabel model yang variabelnya adalah semua variabel bebas. Pada tahap selanjutnya, variabel-variabel bebas yang tersebut dimasukkan dalam pembentukan model. Tabel Model Summary menginformasikan tentang uji untuk seluruh model yang dilakukan.

Model Summary

\begin{tabular}{llll}
\hline Step & -2 Log likelihood & Cox \& Snell R Square & Nagelkerke R Square \\
\hline 1 & $32,426^{a}$ & 0,494 & 0,501 \\
\hline
\end{tabular}

Sumber: output SPSS

Pada Tabel di atas terlihat bahwa berdasarkan uji G, didapat nilai $-2 \log$ likelihood yang merupakan uji seluruh model. Angka sebesar 32,426 cukup besar, apabila dibandingkan dengan nilai $\mathrm{X}^{2}(\mathrm{df}=1)$ sebesar 3,841. Maka dapat disimpulkan bahwa semua variabel signifikan secara statistik pada $\alpha=5 \%$, sehingga seluruh 
variabel dapat dimasukkan dalam model. Tabel berikut merupakan penjelasan nilai estimasi. Uji Wald dan nilai Exp (B), yang kesemuanya merupakan bentuk model yang didapat.

Berdasarkan hasil pengolahan yang dilakukan, maka persamaan model logistik Persamaan yang didapat adalah sebagai berikut:

Ln $(\mathrm{p} / 1-\mathrm{p})=5,531+1,105$ Dummy_Latih(1) - 3,136 Dummy_MI(1) 0,910 Dummy_Didik (1) - 2,854 Dummy_Regulasi (1)

\section{SIMPULAN}

Hasil olahan data mempunyai komposisi untuk nazhir yang setuju wakaf uang sebanyak $81,7 \%$, kemudian untuk nazhir yang tidak setuju wakaf uang sebanyak $18,3 \%$. Secara umum penelitian ini menunjukkan bahwa mayoritas nazhir setuju wakaf uang. Latar belakang pendidikan akan berpengaruh terhadap terbentuknya persepsi atau pemahaman nazhir, karena nazhir yang berpendidikan akan memiliki sikap terbuka terhadap informasi baru dan memandangnya secara obyektif.

Nazhir yang memiliki sedikit informasi tentang wakaf uang sebanyak 0,053 kali dengan yang menyatakan setuju terhadap wakaf uang dibandingkan dengan nazhir yang memiliki banyak informasi. Atau dengan kata lain nazhir yang memiliki banyak informasi sebanyak 9,95 kali dengan yang menyatakan setuju terhadap wakaf uang dibandingkan dengan nazhir yang memiliki sedikit informasi. Nazhir yang tidak paham regulasi sebanyak 0,060 kali dibandingkan dengan nazhir yang paham regulasi. Atau dengan kata lain bahwa nazhir yang menyatakan setuju terhadap wakaf uang dan paham terhadap regulasi wakaf sebanyak 0,94 kali dibandingkan dengan nazhir yang tidak paham regulasi wakaf.

\section{PUSTAKA ACUAN}

Al Arif, M. N. R. 2011. Dasar-dasar Ekonomi Islam. Surakarta: Era Intermedia.

Bamualim, C.S \& I. Abu bakar. 2005. Revitalisasi Filantropi islam, Jakarta : Center for the study of Religion and Culture (CSRC).

De Vito, J.A. 1997. Komunikasi Antar Manusia: Kuliah Dasar, Alih Bahasa Agus Maulana. Jakarta: Profesional Books.

Effendi, M.I. 2007. Faktor-faktor yang Mempengaruhi Persepsi Nasabah Terhadap Program Wakaf Tunai di Dompet Dhuafa (Tesis). Jakarta : Universitas Indonesia.

Hasanah, U. 2005. Menuju Wakaf Produktif. Majalah Gontor, Edisi 12 Tahun II

Kubaisy, M.U.A. 1977. Ahkam al-Waqf fi Syari’a al-Islamiyah, Jilid II. Baghdad : Mathba'ah al-Irsyad. 
Morgan, C.T. 1986. Introduction to Psychology. New York : McGraw - Hill

Mughniyah, M.J. 2007. Fiqih Lima Mazhab Ja'fari, Hanafi, Maliki, Syafi'i dan Hambali. Jakarta: Lentera Basritama.

Mulyana, D. 2007. Ilmu Komunikasi. Bandung : Remaja Rosdakarya.

Munawir, A.W. 2002. Al-Munawwir (Kamus Arab-Indonesia). Surabaya : Pustaka Progresif.

Nachrowi, N.D \& H. Usman. 2002. Penggunaan Teknik Ekonometri. Jakarta : PT. RajaGrafindo Persada.

Najib, T.A. \& R. Al-Makassary. 2006. Wakaf, Tuhan dan Agenda Kemanusiaan. Jakarta : Center for the Study of Religion and Culture (CSRC).

Nawawi, H. \& M. Hadari. 1995. Instrumen Penelitian Bidang Sosial. Yogyakarta : Gadjah Mada University Press.

Nasution, M.E. \& H. Usman. 2007. Proses Penelitian Kuantitatif. Jakarta : Lembaga Penerbit Fakultas Ekonomi Universitas Indonesia.

Nasution, M.E \& U. Hasanah. 2005. Wakaf Tunai Inovasi Finansial Islam, Peluang dan Tantangan dalam Mewujudkan Kesejahteraan Umat. Jakarta : PKTTI UI.

Pusat Bahasa dan Budaya UIN Syarif Hidayatullah Jakarta. 2003. Berderma Untuk Semua. Bandung: Teraju.

Qahaf, M. 2007. Al-Waqfu al-Islami, Tathawuruh, idarasatuh wa Tamiyatuh. Jakarta: Khalifah.

Qardawi, Y. 2001. Peran Nilai dan Moral dalam Perekonomian Islam. Jakarta: Rabbani Press. 